\title{
Features and treatment of gas-forming synergistic necrotizing cellulitis: a nine-year retrospective study
}

\author{
Xiangwei Ling, M.M., ${ }^{*}$ Yuanyuan Ye, M.M., ${ }^{2 *}$ Hailei Guo, M.M., ${ }^{1}$ Zhengjun Liu, M.M., ${ }^{1}$ \\ Weidong Xia, M.M., ${ }^{1}$ Cai Lin, M.D. ${ }^{1}$ \\ 1'Department of Burn, The First Affiliated Hospital of Wenzhou Medical University, Wenzhou, People's Republic of China \\ 2Operating Rooms, The First Affiliated Hospital of Wenzhou Medical University, Wenzhou, People's Republic of China \\ *Xiangwei Ling and Yuanyuan Ye contributed equally and share the first authorship.
}

\begin{abstract}
BACKGROUND: As many doctors know little about gas-forming synergistic necrotizing cellulitis, we retrospectively explored it in our study.

METHODS: Totally, 30 patients diagnosed with gas-forming synergistic necrotizing cellulitis between November 2006 and September 2015 were included. They were divided into two groups: open drainage group (I9 patients) and aggressive debridement group (I I patients). Retrospectively analyzed data comprised demographic characteristics, APACHE II scores, pathogen culture results, bleeding amount during the operation, white blood cell count, length of hospital stay and recovery.
\end{abstract}

RESULTS: The mortality rate was $26 \%$ in the open drainage group and $73 \%$ in the aggressive debridement group ( $p=0.023$ ). There was no statistical difference in the APACHE II score before treatment between the open drainageand aggressive debridement groups $(16.6 \pm 4.5$ vs $18.1 \pm 7.5, p=0.5 \mathrm{II})$. The APACHE II score was significantly higher after treatment in the aggressive debridement group (14.2 \pm 5.8 score vs 20.1 $\pm 9.1, p=0.038)$. There were no statistical differences in the white blood count cell before and after treatment $\left(13.49 \times 10^{9} \pm 5.05 \times 10^{9}\right.$ cells $/ \mathrm{L}$ vs $17.46 \times 10^{9} \pm 6.94 \times 10^{9}$ cells $/ \mathrm{L}, \mathrm{P}=0.082 ; 10.37 \times 10^{9} \pm 3.54 \times 10^{9}$ cells $/ \mathrm{L}$ vs $15.47 \times 10^{9} \pm 7.5 \mathrm{I} \times 10^{9} \mathrm{cell}-$ $s / L, P=0.055$; respectively). The bleeding amount during the operation was significantly more in the aggressive debridement group $(3 \mathrm{I} 5 \pm \mathrm{I} / 2 \mathrm{ml}$ vs $105 \pm 45 \mathrm{ml}, \mathrm{p}<0.00 \mathrm{l}$.

CONCLUSION: For treating gas-forming synergistic necrotizing cellulitis, performing open drainage as early as possible isthe most important procedure after admission.

Keywords: Gas-forming infections; gas gangrene; synergistic necrotizing cellulitis.

\section{INTRODUCTION}

Necrotizing fasciitis is a serious soft tissue infectious disease and is characterized by fascial necrosis and sepsis. ${ }^{\left[{ }^{[l]}\right.}$ Based on the causativebacteria, it canbe divided into two types: type I necrotizing fasciitis is causedby various bacteria, including gram-positive Streptococcus hemolyticus and Staphylococcus aureus and type II necrotizing fasciitis is generally monomicrobial and is typically caused by beta hemolytic Streptococcus. [2] Type I necrotizing fasciitis often occurs in the lower limbs; patients with diabetes and peripheral vascular disease are at a high risk of developing this disease. Sometimes, the neck region or the perineum isalso involved. Necrotizing fasciitis involving the perineum can rapidly spread to the abdominal wall, gluteal muscles, scrotum, and penis. Gas-forming synergistic necrotizing cellulitis is a special category of type I necrotizing fasciitis and is characterized by muscle involvement. Bacillus cereushas beendemonstrated to cause this disease. ${ }^{[3]}$ In clinical settings, gas-forming synergistic necrotizing cellulitis is always considered as gas gangrene. Many doctors believe that no advantage results from the distinction in regard to patient care. ${ }^{[4]}$ In our opinion, gas-forming synergistic necrotizing cellulitis

Cite this article as: Ling X, Ye Y, Guo H, Liu Z, Xia W, Lin C. Features and treatment of gas-forming synergistic necrotizing cellulitis: a nine-year retrospective study. Ulus Travma Acil Cerrahi Derg 2018;24:116-120

Address for correspondence: Cai Lin, M.D.

The First Affiliated Hospital of Wenzhou Medical University, Wenzhou, People's Republic of China Wenzhou, China

Tel: +86-I58680962I3 E-mail: 17798I554@qq.com

Ulus Travma Acil Cerrahi Derg 2018;24(2):116-120 DOI: 10.5505/tites.2017.93453 Submitted: 25.12.2016 Accepted: 04.12.2017 Online: 14.02.2018

Copyright 2018 Turkish Association of Trauma and Emergency Surgery 
and gas gangrene are two different diseases. Gas gangrene has a unique treatment: (I) Extended resection is necessary, such as amputation. The real range of Clostridium infection is wider than it could be observed, extended resection must be done to control infection. ${ }^{[5]}$ (2) Regarding anti-infective therapeutics, penicillin combined with clindamycin is effective against Clostridium. ${ }^{[6]}$ Clindamycin treatment is highly effective in gas gangrene because gas gangrene is caused by an exotoxin whose synthesis is inhibited by clindamycin. ${ }^{[7]}$

While treating gas-forming synergistic necrotizing cellulitis, many doctors tend to perform aggressive debridement in the early period. In their opinion, aggressive debridement needs to be started as early as possible forgettingrid of the necrotic tissue and toxins to improve the chance of patient survival. However, after doing this, many patients die because of massive hemorrhaging. Therefore, we conducted this retrospective study to find a better treatment and explored the features of this disease.

\section{MATERIALS AND METHODS}

\section{Ethics}

This study was approved by our local medicotechnical committee (Wenzhou Medical Association, Wenzhou, China).

\section{Data Collection}

A retrospective review was performed onthe medical records of all patients who were admitted to our hospital between November 2006 and September 2015 and who metthe study criteria. Inclusion criteria were (I) serious infection of the lower limbs or perineum (Fig. Ia, b), (2) infection involving muscle layers, and (3) subcutaneous emphysema (Fig. Ic, d). Exclusion criteria were (I) incomplete clinical information (2) patients givingup treatment and (3) gas gangrene. Clinical data included age, gender, location of infection, underlying disease, APACHE II score, pathogen culture results, bleeding amount during the operation, white blood cell count,length of hospital stay, and recovery.

\section{Microbiological Methods}

For pathogen cultures, blood agar and Sabouraud dextrose agar were utilized for all specimens. Physicians then selected the pathogens thought to be suitable. VITEK 2 Compact was used for identification. Minimum inhibitory concentrations were assessed during drug sensitivity tests.

\section{Treatment}

\section{Early Stage Intervention}

According to the medical records, 19 patients underwent
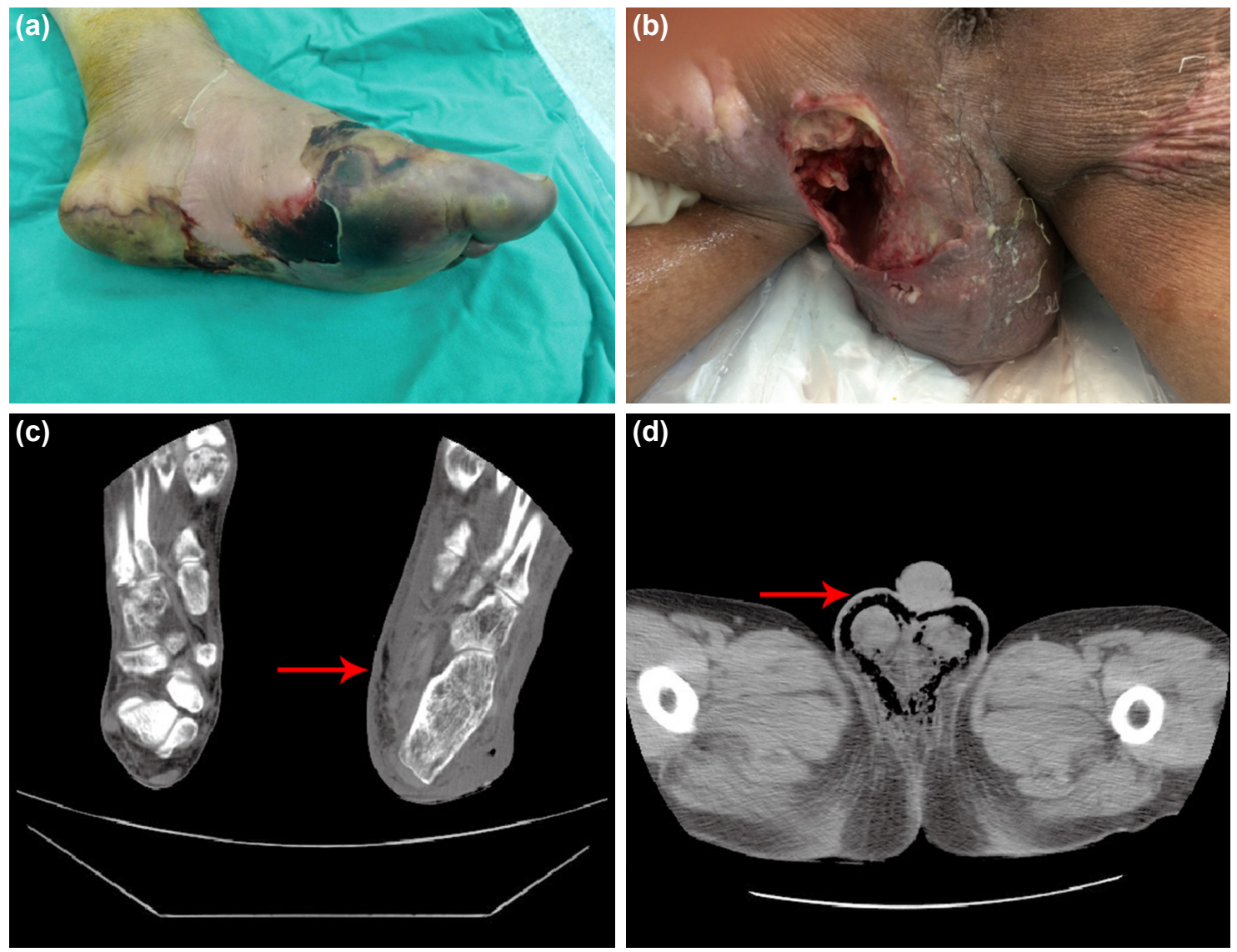

Figure 1. (a) The left foot was seriously infected, and the tissues were severelydamaged. (b) The perineum was ruptured and exuded. (c) The left foot was overly swollen; radiography demonstrated soft tissue emphysema medially (arrow). (d) The scrotum had large amounts of gas inthe radiograph (arrow). 
Table I. Patient characteristics and mortality rates in open drainage $(n=19)$ and aggressive debridement $(n=\mid 1)$ groups

\begin{tabular}{|c|c|c|c|c|c|c|c|}
\hline \multirow[t]{2}{*}{ Variable } & \multicolumn{3}{|c|}{ Open drainage group } & \multicolumn{3}{|c|}{ Aggressive debridement group } & \multirow[t]{2}{*}{$\mathbf{p}$} \\
\hline & $\mathbf{n}$ & $\%$ & Mean $\pm S D$ & $\mathbf{n}$ & $\%$ & Mean $\pm S D$ & \\
\hline Sex, male & 13 & 68 & & 8 & 73 & & 1.000 \\
\hline Age (years) & & & $57.8 \pm 8.5$ & & & $56.4 \pm 20.6$ & 0.824 \\
\hline Liver disease & 7 & 37 & & 5 & 45 & & 0.712 \\
\hline Diabetes mellitus & 12 & 63 & & 6 & 55 & & 0.712 \\
\hline Location of infection, lower limbs & 17 & 89 & & 10 & 91 & & 1.000 \\
\hline Mortality rate & & 26 & & & 73 & & 0.023 \\
\hline
\end{tabular}

SD: Standard deviation.

open drainage (open drainage group) and II underwent aggressive debridement (aggressive debridement group) as early as possible after admission. In the open drainage group, two ways were recommended for drainage: (I) incisions at the apparent position of crepitus. (2) removal part of necrotic tissues created open drainage. In the aggressive debridement group, all necrotic tissues were removed. Then, broad-spectrum antibiotics and support treatment were provided. Negative pressure wound therapy was not used for these wounds in the early duration.

\section{Later Stage Intervention}

In the following days, dressings were changed and wounds were observed. A rapidly spreading infection was indicative of gas gangrene. Empiric treatment for gas gangrene was implemented, such as extended resection, anti-infective therapeutics (penicillin combined with clindamycin), and amputation. In case of gradual infection, patients were diagnosed with gas-forming synergistic necrotizing cellulitis. In the open drainage group, aggressive debridement was not performed until the vital signs became stable. The dressings were changed, necrotic tissueswere removed, and bleeding amount was reduced by as much as possible. In the aggressive debridement group, the dressings were changedto promote granulation. Antibiotics were changed depending on culture results. Cultures from the 30 patients yielded 42 different species. The most prevalent organisms were Staphylococcus ( $n=6,14.3 \%$ ) (Staphylococcus aureus, S. haemolyticus, S. epidermidis, S. hominis), Proteus $(\mathrm{n}=6,14.3 \%)$ (Proteus vulgaris, P. mirabilis), Klebsiella pneumonia $(\mathrm{n}=5,11.9 \%)$, Enterococcus $(n=5,11.9 \%)$, Stenotrophomonas maltophilia $(n=2,4.8 \%)$, Escherichia coli ( $n=2,4.8 \%)$, Streptococcus $(n=2,4.8 \%)$, Citrobacter $(n=2,4.8 \%)$, and Corynebacterium $(n=2,4.8 \%)$. Acinetobacterbaumannii, Raoultellaplanticola, Rhodococcus equi, Serratia marcescens, Pseudomonas mendocina, Morganella morganii, Enterobacter cloacae, Pseudomonas aeruginosa, Myroides, and Aeromonas caviae. The wounds were finally repaired using skin grafting.

\section{RESULTS}

\section{Patient Characteristics and Mortality Rates}

Thirty patients ( 21 males and 9 females) with a mean age of 57.3 years [standard deviation (SD), 13.8] were reviewed. Twenty-sevenpatients had infection that involved the lower limbs and threehad infection that involved the perineum. Eighteenpatientshad diabetes mellitus and 12 had liver disease. The median APACHE II score after hospitalization was 17.2 (SD, 5.7). The median length of hospital stay was 29.2 days (SD, 23.7). A total of I 3 patients died (mortality rate of $43 \%$ ). Among the 14 patients who were successfully treatedfor infection involving the lower limbs, one underwentamputation. There was no statistical difference in terms of age, gender, underlying diseases(diabetes mellitus or liver disease), and position between the open drainage and aggressive debridement groups. The mortality rate was $26 \%$ in the open drainage group and $73 \%$ in the aggressive debridement group (Table I).

\section{Changes in the APACHE II Score and White Blood Cell Count After Treatment and Bleeding Amount During the Operation}

The APACHE II score was significantly higherafter treatment

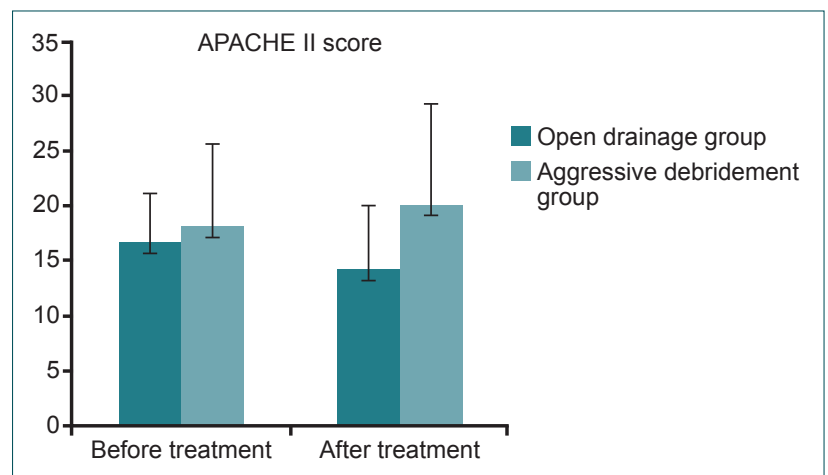

Figure 2. There was no statistical difference in the APACHE II score before treatment between the open drainage and aggressive debridement groups $(16.6 \pm 4.5$ vs $18.1 \pm 7.5, p=0.511)$. The APAC$\mathrm{HE}$ II score was significantly higher after treatment in the aggressive debridement group $(14.2 \pm 5.8$ vs $20.1 \pm 9.1, p=0.038)$. 


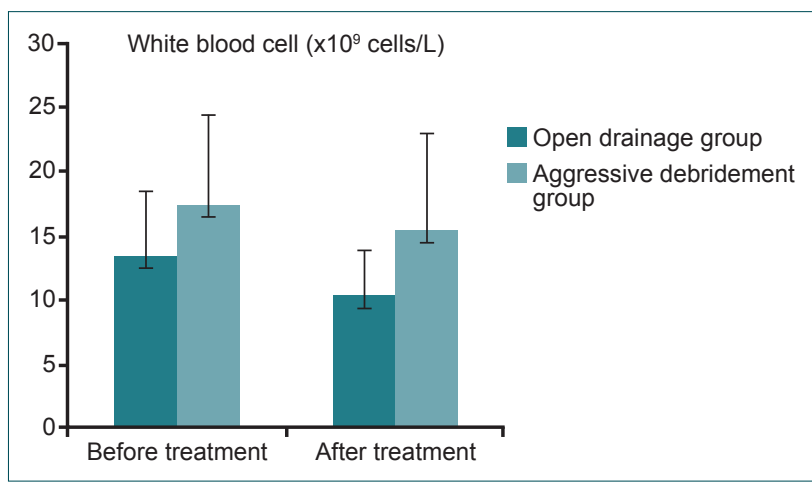

Figure 3. There was no statistical difference in the white blood cell count before and after treatment between the open drainage and aggressive debridement groups $\left(13.49 \times 10^{9}\right.$ cells $/ \mathrm{L} \pm 5.05 \times 10^{9}$ cells $/ \mathrm{L}$ vs $17.46 \times 10^{9}$ cells $/ \mathrm{L} \pm 6.94 \times 10^{9} \mathrm{cells} / \mathrm{L}, \mathrm{p}=0.082 ; 10.37 \times 10^{9}$ cells $/ \mathrm{L} \pm 3.54 \times 10^{9}$ cells $/ \mathrm{L}$ vs $15.47 \times 10^{9} \mathrm{cells} / \mathrm{L} \pm 7.51 \times 10^{9} \mathrm{cells} / \mathrm{L}$, $\mathrm{p}=0.055)$.

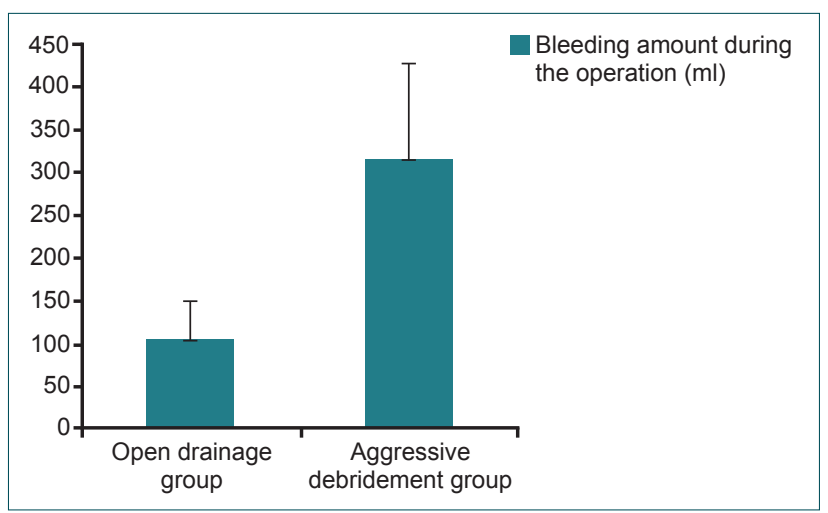

Figure 4. The bleeding amount during the operation was significantly less in the open drainage group $(105 \pm 45 \mathrm{ml}$ vs $315 \pm 112 \mathrm{ml}$, $\mathrm{p}<0.001)$.

in the aggressive debridement group (Fig. 2). There was no statistical difference in the white blood cell count before and after treatment between the open drainage and aggressive debridement groups (Fig. 3). The bleeding amount during the operation was $315 \pm 112 \mathrm{ml}$ inthe aggressive debridementgroup, which was significantly higherthan that in the open drainagegroup ( $105 \pm 45 \mathrm{ml}$; $<0.00 \mathrm{l}$ ) (Fig. 4).

\section{DISCUSSION}

Gas-forming synergistic necrotizing cellulitis is a very serious and rare disease. Surgery, antimicrobial therapy, and support treatment areessential early interventions. Surgery is thought to be the most important to improve the survival rate and should be conductedas early as possible. ${ }^{[8]}$ Unfortunately, doctors do not know how to conductthe surgery. They think that aggressive debridement is the best way. After many years of treatingpatients with gas-forming synergistic necrotizing cellulitis, we have gained some experience. Gasforming synergistic necrotizing cellulitis requires immediate surgery thatneeds to be started as early as possible to improve the chances of patient survival. Waiting for bacterial culture growth, which takes several days, is not an option. During the operation, open drainage is the most important procedure; reducing the bleeding amount should also be considered. These patients always show unstable vital signs and poor coagulation function and cannot tolerate aggressive debridement. In our study, we found that the APACHE II score was significantly higher after treatment in the aggressive debridement group. The bleeding amount during the operation was significantly more in the aggressive debridement group. Based on the white blood cell count, we inferredthat open drainage can also control inflammation and infection.

After the surgery, doctors must observe the wound and carry out the differential diagnosis of gas gangrene in the following days. Gas gangrene, as a gas-forming infection, is caused by Clostridium, which is a large gram-positive rod. Predisposing conditions for gas gangrene include local trauma or surgery; synergistic necrotizing cellulitis is often found in patients with diabetes mellitus and perirectal infection. The incubation period of gas gangrene is much shorter than that of synergistic necrotizing cellulitis, and the range of muscle infectionis much larger in gas gangrene. In China, some doctors do not pay much attention to wounds in the early period; this results indeath. For example, Wen treated five patients with gas-forming infections; one died because more attention was paid to the vital signs, ignoring the wounds. The others survived because the authorsobserved the rapidly spreading wounds and treated them as gas gangrene. ${ }^{[9]}$ Fu-Qiang treated seven patients; they all died because the authorsignored the wounds and it was too late when they identify Clostridium. [10] After many years of treatment, we hadaccumulated experiences. On the first day, immediate open drainage and broad-spectrum antibiotics were administered. Subsequently, the wounds did not deteriorate, patients were diagnosed with gas-forming synergistic necrotizing cellulitis. We partly removed necrotic tissues when we changed the dressings. Until the vital signs stabilized, aggressive debridement wasperformed. Finally, the patients were cured. Negative pressure wound therapy is useful for treating wounds, such as diabetic foot. ${ }^{[1]}$ However, there is little evidence that it can be used for gas-forming infections in the early period. In our opinion, it is inappropriate to control infection and inhibit aerogenic bacteria. If debridement is aggressively done in the later period, negative pressure wound therapy is a good option. ${ }^{[12]}$

Regarding the underlying diseases, the most frequent is diabetes mellitus. It was found in $60 \%$ of the patients in our study. Infectious wounds in diabetes are thought to be associated with neuropathy and angiopathy, and advanced glycation end products are initiating agents. ${ }^{[13,14]}$ The reason why diabetes mellitus is a co-morbidity in patients with synergistic necrotizing cellulitis isunknown. In our opinion, advanced glycation end products may offer a good environment for the bacteria of synergistic necrotizing cellulitis, and diabetes patients have no resistance to the bacteria. Gender was proposed as another risk factor, with men having a higher chance 
of being infected. This percentage was $70 \%$ in our study; however, some researchersshowed there was no correlation. ${ }^{[15,16]}$

The major limitation of our study is that it was retrospective; aprospective study needs to be conducted. Another limitation is that thestudy did not assess many patientsand that the patients were from one medical center; anotherfurther multi-institutional study to strengthen our findings is required. Despite these limitations, we founda new surgical procedure thatis of great significance for treating gas-forming synergistic necrotizing cellulitis.

\section{Acknowledgments}

This study was supported by the Zhejiang Provincial Natural Science Foundation of China (Grant No. Z2080985) and the Science and Technology Program of Wenzhou (Grant No. Y20I50273,Y20I60328, and Y20I40I87).

Conflict of interest: None declared.

\section{REFERENCES}

1. Sturgeon JP, Segal L, Verma A. Going Out on a Limb: Do Not Delay Diagnosis of Necrotizing Fasciitis in Varicella Infection. Pediatr Emerg Care 2015;31:503-7. [CrossRef]

2. Davoudian P, Flint NJ. Necrotizing fasciitis. Continuing Education in Anaesthesia Critical Care \& Pain 2012:245-50. [CrossRef]

3. Sada A, Misago N, Okawa T, Narisawa Y, Ide S, Nagata M, et al. Necrotizing fasciitis and myonecrosis "synergistic necrotizing cellulitis" caused by Bacillus cereus. J Dermatol 2009;36:423-6. [CrossRef]

4. Brucato MP, Patel K, Mgbako O. Diagnosis of gas gangrene: does a discrepancy exist between the published data and practice. J Foot Ankle Surg 2014;53:137-40. [CrossRef]

5. Pragatheeswarane M, Balaji NN, Duvuru S, Gubbi Shamanna S. Gas gangrene: need for aggressive management in delayed presentation. Surg Infect (Larchmt) 2014;15:361-2. [CrossRef]

6. Gilbert D, Moellering R, Eliopoulos G. The Sanford Guide to Antimicrobial Therapy. 40th ed. Sperryville, VA: Antimicrobial Therapy; 2010.

7. Stevens DL, Aldape MJ, Bryant AE. Life-threatening clostridial infections. Anaerobe 2012;18:254-9. [CrossRef]

8. Chao WN, Tsai CF, Chang HR, Chan KS, Su CH, Lee YT, et al. Impact of timing of surgery on outcome of Vibrio vulnificus-related necrotizing fasciitis. Am J Surg 2013;206:32-9. [CrossRef]

9. Qin W, Li GY, Zeng YD. Early treatment experience of gas gangrene. Chinese Journal of Traditional Medical Traumatology \& Orthopedics 2007;15:27-8.

10. He FQ, Li QY. Death causes of gas gangrene. People's Military Surgeon 2002;45:437-8.

11. Isaac AL, Armstrong DG. Negative pressure wound therapy and other new therapies for diabetic foot ulceration: the current state of play. Med Clin North Am 2013;97:899-909. [CrossRef]

12. Hu N, Wu XH, Liu R, Yang SH, Huang W, Jiang DM, et al. Novel application of vacuum sealing drainage with continuous irrigation of potassium permanganate for managing infective wounds of gas gangrene. J Huazhong Univ Sci Technolog Med Sci 2015;35:563-8. [CrossRef]

13. Liu C, Xu L, Gao H, Ye J, Huang Y, Wu M, et al. The association between skin autofluorescence and vascular complications in Chinese patients with diabetic foot ulcer: an observational study done in Shanghai. Int J Low Extrem Wounds 2015;14:28-36. [CrossRef]

14. Lu W, Li J, Ren M, Zeng Y, Zhu P, Lin L, et al. Role of the mevalonate pathway in specific $\mathrm{CpG}$ site demethylation on AGEs-induced MMP9 expression and activation in keratinocytes. Mol Cell Endocrinol 2015;411:121-9. [CrossRef]

15. Benjelloun el B, Souiki T, Yakla N, Ousadden A, Mazaz K, Louchi A, et al. Fournier's gangrene: our experience with 50 patients and analysis of factors affecting mortality. World J Emerg Surg 2013;8:13. [CrossRef]

16. Morua AG, Lopez JA, Garcia JD, Montelongo RM, Guerra LS. Fournier's gangrene: our experience in 5 years, bibliographic review and assessment of the Fournier's gangrene severity index. Arch Esp Urol 2009;62:532-40.

\section{ORIJINAL ÇALIŞMA - ÖZET}

Gaz oluşumuyla karakterize sinerjistik nekrotizan selülit özellikleri ve tedavisi: Dokuz yılı kapsayan geriye dönük çalışma

\section{Dr. Xiangwei Ling, ${ }^{1}$ Dr. Yuanyuan Ye, ${ }^{2}$ Dr. Hailei Guo, ${ }^{1}$ Dr. Zhengjun Liu, ${ }^{1}$ Dr. Weidong Xia, ${ }^{1}$ Dr. Cai Lin ${ }^{1}$}

${ }^{1}$ Wenzhou Tıp Üniversitesi Hastanesi, Yanık Bölümü, Wenzhou-Çin Halk Cumhuriyeti

${ }^{2}$ Wenzhou Tıp Üniversitesi Hastanesi, Ameliyathaneler, Wenzhou-Çin Halk Cumhuriyeti

AMAÇ: Birçok doktor gaz oluşumuyla karakterize sinerjistik nekrotizan selülit hakkında az bilgi sahiptir, çalışmamızda bu durumu geriye dönük araştırdık.

GEREÇ VE YÖNTEM: Kasım 2006 ile Eylül 2015 arasında gaz oluşumuyla karakterize sinerjistik nekrotizan selülit tanısı konmuş toplam 30 hasta çaış̧maya alındı. On dokuz hastaya açık drenaj uygulandı, I I hastaya agresif debridman yapıldı. Geriye dönük olarak demografiler, APACHE II skorları, patojenlerin kültür sonuçları, ameliyat sırasında kanama miktarı, beyaz küreler ve derlenme geriye dönük olarak incelendi.

BULGULAR: Ölüm oranları açık drenaj ve agresif debridman gruplarında sırasıyla $\% 26$ ve $\% 73$ idi $(p=0.023)$. Tedavi öncesinde iki grup arasında APACHE II skorları açısından herhangi bir istatistiksel farkllık yoktu ( $16.6 \pm 4.5^{\prime}$ 'e karşın I8. I $\pm 7.5, p=0.5 \mathrm{I}$ I). Tedavi sonrasında agresif tedavi

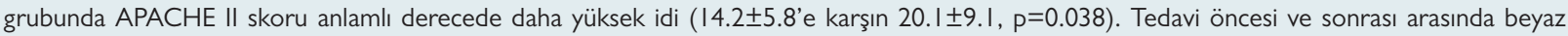
küre sayısında istatistiksel farklılık yoktu $\left(13.49 \pm 5.05 \times 10^{9}\right.$ hücre/L'e karşın $17.46 \pm 6.94 \times 10^{9}$ hücre/L, $p=0.082 ; 10.37 \pm 3.54 \times 10^{9}$ hücre $/ \mathrm{L}$ ve $15.47 \pm 7.5 \mathrm{I} \times 10^{9}$ hücre $\left./ \mathrm{L}, \mathrm{p}=0.055\right)$. Ameliyat sırasında kanama agresif debridman grubunda anlamlı derecede daha fazla idi $(3 \mid 5 \pm$ I I $2 \mathrm{ml}$ 'ye karşın $105 \pm 45 \mathrm{ml}, \mathrm{p}=0.000)$.

TARTIŞMA: Sinerjistik nekrotizan selülit tedavisi için hasta kabulden sonra olabildiğince en kısa sürede açık drenaj yapılacak en önemli girişimdir. Anahtar sözcükler: Gaz oluşturan enfeksiyonlar; gazlı kangren; sinerjistik nekrotizan selülit.

Ulus Travma Acil Cerrahi Derg 2018;24(2):1 I6-120 doi: 10.5505/tjtes.2017.93453 